\title{
Green Quality Improvement Using Six Sigma Method
}

\author{
Sutrisno Harianto \\ Master Degree Program in Industrial Engineering in \\ National Institute Of Technology (ITN) \\ Malang, Indonesia
}

\begin{abstract}
Traditional cast brass handicrafts Majapahit is one of the nation's cultural heritage which has a high historical value. The uniqueness and quality become the hallmark of this craft products. The results of handmade products such as sculptures, wall hangings, souvenirs, ornaments doors and so on. To increase the sales of traditional handicrafts of brass castings, required Majapahit applicative technical efforts in improving the quality of products which are ecofriendly. Quality improvement method such as Six sigma. Six sigma focuses on decreasing flawed rate, by reaching the standard 3,4 flawed in a thousand possibility. Six sigma has 5 phases; define, measure, analyze, improvement, and control. In this research, six sigma is applied in producing cast brass handicraft starting from making the master mold, preparation of smelting raw materials, cooling process, releasing of the mold, and finishing. Purposefully to improve the quality by overcoming and decreasing the high of flawed possibility and also applying marketing mixture in improving the market segmentation of traditional cast brass of Majapahit market. The result is quality improvement is shown by decreasing happen in number of flawed product in total of mean for about 154, 8 decreased to 59,5. While the calculation of the six sigma, flawed product of cast brass handicraft is for about 1,7625 sigma value or being in level 2 and increased to 3,725 or being in level 4 with the flawed possibility in amount 235,000 for thousand times of production. The ability of production for the requirement which is wanted by the consumers and owning a good enough capability but still needed some correction to achieve world class home industry
\end{abstract}

Keywords:- Defect, Green Quality Improvement, Six Sigma, Traditional Brass Casting Craft.

\section{INTRODUCTION}

The craftsmen traditional Majapahit cast brass joined in a ganesha cooperative formed in 2005. The quality of eco-friendly improvement or green quality improvement is now very popular for consumers [1],[2],[3]. It is shown by the greater awareness of consumers to obtain an adequate, safe, and eco-friendly product. Consumers are willing to pay more for eco-friendly products [4].

Changes in consumer awareness has led to large and small industries indirectly must pay attention to the environment and are responsible for not harming the environment. Resulting product is not only feasible and safe but in the production process must be clean and eco-friendly

\author{
Ellysa Nursanti \\ Lecturer in Industrial Engineering Department, Postgraduate \\ Program National Institute of Technology (ITN) \\ Malang, Indonesia
}

[2],[3]. Brass craft industry SMEs are required to pay attention to the surrounding environment in production process and produce products that are safe and consumeable by consumers.

\section{DESCRIPTION SYSTEM}

The production process of making Majapahit brass cast sculpture in Bejijong village is still traditional using simple equipment. The production system begins with the making of the master mold and preparation of raw materials, then the casting process is carried out, then the cooling process and removal of the cast sculpture from the mold, as well as the finishing and coloring process.

Green quality improvement or green quality improvement is now very popular with consumers. This is shown by the greater awareness of consumers to get products that are feasible, safe and environmentally friendly. Consumers are willing to pay more for products that do not damage the environment or are environmentally friendly.

This change in consumer awareness results in large and small industries indirectly having to pay attention to the environment and take responsibility not to damage the environment. The product produced is not only feasible and safe but in the production process it must be cleaner and more environmentally friendly.

The biggest obstacle faced by craftsmen in an environmentally friendly production process is the absence of definitive work operating standards. To meet the quality of national and international standard products that are environmentally friendly, it requires an applicable standardization of production processes so that quality standards can be achieved.

\section{METHODOLOGY}

The production process of making Majapahit brass sculptures still using traditional equipment. The production system begins from making the master mold and preparation of raw materials, the casting process is performed, then cooling process and the release of sculptures cast from the mold, as well as finishing and dyeing processes.

The production process of making Majapahit brass cast is still traditional using simple equipment. The production system begins with the making of the master mold and preparation of raw materials, then the casting process is carried out, then the cooling process and removal of the cast 
sculpture fromthe mold, as well as the finishing and coloring process.

The brass cast craftsmen are incorporated in the Ganesha cooperative that was formed since 2005. Researchers are very interested in the traditional brass cast of Majapahit because until now it is still survive in modern era. From the results of preliminary observations obtained the average sales data of brass cast craftsmen which came from the members of the Ganesha cooperative for one year.

From the survey results in the field of data in general the total production is 3,000 units to 1,239 units the number of defective products. After doing research in the field of product defects, can be broadly categorized types of defects were found to be four types: defects or perforated holes , disability rats, rough surface defects and disability cracks. The research stages can be seen in Figure 1 below:

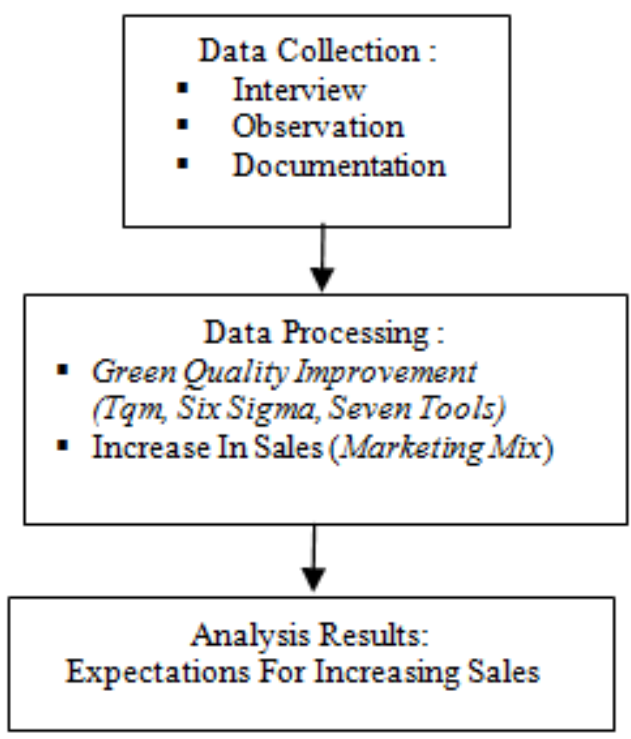

Fig 1:- Research Stage

\section{RESUTS AND DISCUSSIONS}

The results of several previous studies are still in the form of normative suggestions, there are no clear operating standards for work, there is no standardization of processes, equipment, materials and supervision. The research only discusses application theory, quality improvement and sales which have no consideration to eco-friendly factors.

Thus, this research is important to be carried out to improve the quality and sales of Majapahit's traditional brass cast products which are eco-friendly. By increasing human resources, standardizing processes, equipment, materials and supervision, eco-friendly production efficiency can be achieved

Based on observations and interviews with cast brass craftsmen joined in cooperative direct Ganesha, the most dominant cause of the product defect occurs in: the process of making a master mold, raw material melting process, the process casting.
Factor causes of these defects are caused and are directly related to humans, machines, methods, materials, and environment [5]. Work shown in Figure 2 Fishbone diagram.

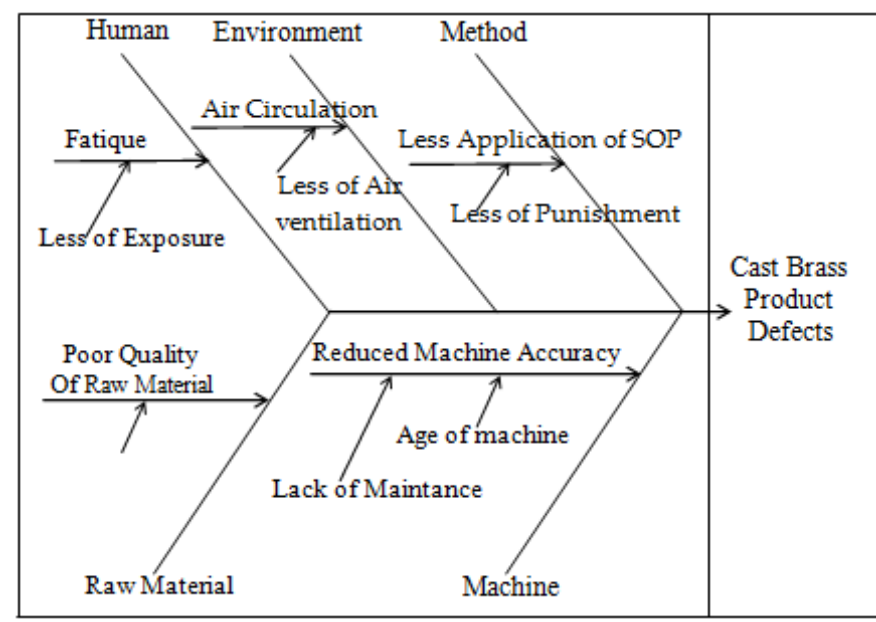

Fig 2:- Fishbone Diagram

Product defect repair process to define a process improvement process model needs to be known to be used, namely Suppliers - Inputs - Processes - Outputs - Customers shown in Figure 3.

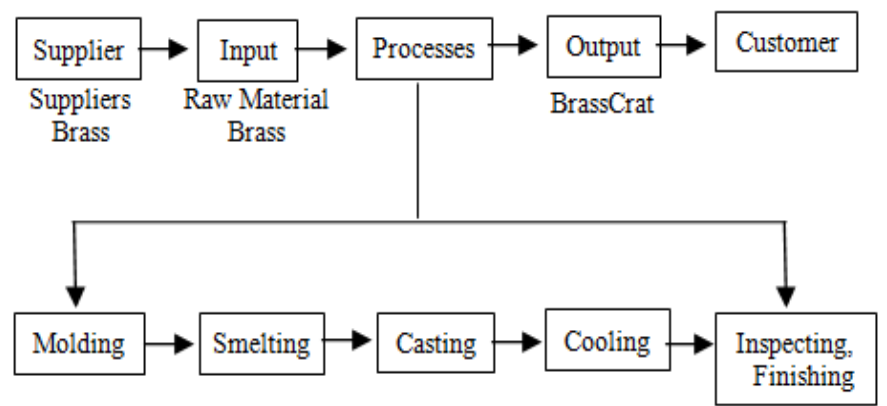

Fig 3:- Suppliers-Inputs-Processes-Outputs-Customers

Suppliers - Inputs - Processes - Outputs - Customers diagram illustrates the process becoming the focus of the project. There are five elements of this diagram are: Supplier of raw materials such as brass collectors or trashy brass scrap materials in the surrounding craftsmen's area. Input the process is brass which had been merged in the Smelting Process. Process, Consisting of Molding, Smelting, Casting, Cooling, Inspecting and Finishing. Output after all stages of the process is done it will produce cast brass handicraft products. Customer, Is the process of the finished product to the customer.

\section{A. Counting Defect Per Unit and Defect Per Million Objects}

Before calculating process capability, first calculate the value of Defect Per Unit [6]-[7]. Defect Per Unit calculation is to give a general idea of the number of defects that occur every unit. In this study, the unit is categorized brass casting product, so that the meaning Defect Per Unit is the number of defects that occur in every cast brass products. Defect Per Unit value calculation is generally obtained from a simple 
calculation, the number of defects divided by the total number craft production of cast brass.
The following is a comparison of the number of defects that occur in every cast brass products shown in Table 1.

\begin{tabular}{|c|c|c|c|c|c|}
\hline No. & Total Production & Total Disability & Defect Per Unit & Defect Per Million Objects & Sigma value \\
\hline 1 & 250 & 106 & 0.424 & 424000 & 1.65 \\
\hline 2 & 250 & 97 & 0,388 & 388000 & 1.75 \\
\hline 3 & 500 & 234 & 0.468 & 468000 & 1.55 \\
\hline 4 & 500 & 229 & 0.458 & 458000 & 1.65 \\
\hline 5 & 500 & 244 & 0,488 & 388000 & 1.55 \\
\hline 6 & 250 & 75 & 0.3 & 300000 & 2.05 \\
\hline 7 & 250 & 69 & 0,276 & 276000 & 2.05 \\
\hline 8 & 500 & 185 & 0.37 & 370000 & 1.85 \\
\hline mean & 375 & 154.875 & 0.3965 & 396500 & 1.7625 \\
\hline
\end{tabular}

a.The results of Author's research

Table 1:- Detect Per unit and detect er million objects.

From the calculation of Table 1, it can be seen that the defects of brass handicraft products reach the sigma level of 1.7625 or are at the level 2 sigma condition with a possible damage of 396,500 for a million times the production process or $39.65 \%$ Defect Per Million Objects.

This certainly becomes a loss for craftsmen if there is no improvement in the production process. To reduce the level of product damage or defects produced, it is necessary to increase the level of sigma in each production process.

\section{B. Improve Phase}

The aim of the improve phase is to find and implement solutions that will eliminate the cause of the problem, reduce variety process and also prevent the same mistakes happen. There some ways to reach those aims for instance.

\section{Generate Creative Ideas}

This creative idea aims to develop the Majapahit traditional brass cast industry, especially in the production process. The creative ideas that are possible to do are:

Design development and mold making this mold design is made manually, it is possible to use computer numerically controlled. In addition to good accuracy, the speed can also be measured so that it can save production time.

Development of furnaces traditional burning stoves used to use firewood as fuel. This process requires a long time in heating and the heating results are also uneven. The resulting temperature cannot be stable in the heating chamber often causes one of the factors causing failure in the production process. By using modern furnace commonly used in the ceramic industry, the heat produced is stable and can be measured so that the perfection of the results can be achieved. Besides that the shorter time in the combustion process, the less pollutants produced, let alone using electricity, and the environmentally friendly production process can be achieved.
Development of metal-chemical coating techniques brass metal coloring is still done by craftsmen of Majapahit brass cast. So that the resulting colors are not evenly distributed in certain parts. By using metal-chemical coating techniques in addition to coating the metal it is also able to resist corrosion of the metal. The resulting color is more flexible and varied so that it can meet customer desires.

The application of green productivity in eco-friendly quality improvement is laid out Waste Reduction. By applying 3R; reduce, reuse, and recycle as an effort to improve the quality which is eco-friendly [8],[2],[3]. Suggestions of 3R's application in cast brass handicraft in home industry; Reducing the using of firewood or charcoal in burning process changed by using gas. Reuse the remains of sand mold is able to be smelted and reused for the mold of the next production. Recycle is using raw material from trash which made from brass recycled in smelted raw material.

From the shorter time in the combustion process, the less pollutants produced, let alone using electricity, and the environmentally friendly production process can be achieved [9],[10],[11],[12],[13]. Development of metalchemical coating techniques. Brass metal coloring is still done by craftsmen of Majapahit brass cast. So that the resulting colors are not evenly distributed in certain parts.

By using metal-chemical coating techniques in addition to coating the metal it is also able to resist corrosion of the metal. The resulting color is more flexible and varied so that it can meet customer desires.

\section{$>$ Material Management}

Material here is the pure brass or wreckage of brass which has been processed before. The function of material management is responsible in planning, sourcing, purchasing, storing, and controlling [14]. 
Suggestions of material management's application in home industry of cast brass handicraft; planning an accurate plan in the application of raw material depends on consumers' request. Sourcing having cooperation with brass wreckage wholesaler for being supplier of brass. Purchasing of raw material can be cooperating with Ganesha cooperation as colleague of craftsman in case of fund. Storing by the limit of the land.

Craftsman should have a warehouse to save the raw material coordinated by the cooperation. Controlling the use of raw material through the cooperation hopefully the availability of raw material is guaranteed. Preventing the crisis of raw material which causes rising price of material as balancer of material price in market.

\section{Marketing Mix Brass Craft Product}

The marketing of brass cast crafts has only relied on orders from customers, especially customers who have art shops in the cities of Bali and Yogyakarta. To increase sales, a system that is used in marketing (marketing mix) [15],[16],[17] is needed, which includes:
Cast brass handicraft products offered must be able to meet consumers desires and needs. Especially in the guarantee of product quality, and timeliness in accordance with the order.

The price of brass craft products must be able to compete with other products on the market. By following the standard market prices both domestically and abroad.

Place in (marketing mix) commonly referred to as distribution channels, in this case from brass cast craftsmen to the hands of customers. Special delivery or express package makes it easy to send or distribute products with additional shipping costs adjusted for distance.

Promotion of marketing spread both directly (direct marketing) and by using technological advances, especially the internet. To reach marketing to international level, you can use internet access or social media, for example (Facebook).

\section{Standardization of Brass Craft Process Acording to MMSE}

Based on a survey of good product results in SMEs cast brass craftsmen who are members of the Ganesha cooperative. Then it can be concluded in a standard table [18] of production processes that can produce good products shown in Table 2.

\begin{tabular}{|c|c|c|c|}
\hline No & Stages of production & Tools or materials & Process \\
\hline 1 & $\begin{array}{l}\text { Making master } \\
\text { mold }\end{array}$ & Cement and Silicone & $\begin{array}{l}\text { Giving oil for every five times in making } \\
\text { wax molds }\end{array}$ \\
\hline 2 & Smelting raw materials & Smelting furnaces and brass metal & $\begin{array}{c}\text { Sifting materials from a mixture of other } \\
\text { materials to produce pure metal brass for } \\
\text { raw materials is obtained from brass } \\
\text { wraps }\end{array}$ \\
\hline 3 & Casting & Metal thermometer (Thermocouple) & $\begin{array}{c}\text { The casting process is carried out at a } \\
\text { temperature of } 9000^{\circ} \text { Celsius }-1.0500^{\circ} \\
\text { Celsius }\end{array}$ \\
\hline 4 & Cooling & Fan (Air Cooler) & $\begin{array}{l}\text { Brass cast results are placed in an open } \\
\text { space with free air circulation }\end{array}$ \\
\hline 5 & Welding & Clamping tools (Vise) & $\begin{array}{l}\text { Every connecting welding process uses } \\
\text { clamps so the results can be precise and } \\
\text { even }\end{array}$ \\
\hline 6 & Refining & Grinding and Green stone & $\begin{array}{l}\text { Giving a polished green stone every time } \\
\text { is used for five brass craft units }\end{array}$ \\
\hline 7 & Staining & $\begin{array}{l}\text { Stainless steel container, material for } \\
\text { antique green color (BTC MS 040 T } \\
250 \text { gram and BTC 047T } 250 \text { gram } \\
\text { for every } 5 \text { liters of water }\end{array}$ & $\begin{array}{c}\text { Mix all ingredients in a stainless steel } \\
\text { container and heat it to a temperature of } \\
700^{\circ} \text { Celsius then dip brass metal for one } \\
\text { minute }\end{array}$ \\
\hline
\end{tabular}

ь. The results of Author's research

Table 2:- Standart Cast Brass Production Process.

Final expectation of the value of sigma after improvement.

From the results of improvement, it is expected that the change in the value of Sixma is better than before [28],[29]. This means an increase in the value of sixma in accordance with the desired expectations. After an experiment of improvement for four months there was a change in the value of sigma.

The following is a comparison of the sigma values of the production process before and after improvements are made as shown in Table 3. 
ISSN No:-2456-2165

\begin{tabular}{|c|c|c|c|c|c|c|c|c|c|}
\hline \multirow{3}{*}{ No } & \multirow{3}{*}{$\begin{array}{c}\text { Total } \\
\text { Product }\end{array}$} & \multirow{2}{*}{\multicolumn{2}{|c|}{ Total Disability }} & \multirow{2}{*}{\multicolumn{2}{|c|}{$\begin{array}{l}\text { Defect } \\
\text { Per Unit }\end{array}$}} & \multirow{2}{*}{\multicolumn{2}{|c|}{$\begin{array}{c}\text { Defect } \\
\text { Per Million Objects }\end{array}$}} & \multirow{2}{*}{\multicolumn{2}{|c|}{ Sigma Value }} \\
\hline & & & & & & & & & \\
\hline & & before & After & before & After & before & After & before & After \\
\hline 1 & 250 & 106 & 52 & 0.424 & 0.208 & 424000 & 208000 & 1.65 & 3.55 \\
\hline 2 & 250 & 97 & 43 & 0,388 & 0.172 & 388000 & 172000 & 1.75 & 3.65 \\
\hline 3 & 500 & 234 & 80 & 0.468 & 0.36 & 468000 & 360000 & 1.55 & 3.65 \\
\hline 4 & 500 & 229 & 67 & 0,458 & 0.35 & 458000 & 350000 & 1.65 & 3.8 \\
\hline 5 & 500 & 244 & 93 & 0,488 & 0.38 & 488000 & 380000 & 1.55 & 3.5 \\
\hline 6 & 250 & 75 & 21 & 0.3 & 0.84 & 300000 & 84000 & 2.05 & 4.25 \\
\hline 7 & 250 & 69 & 15 & 0,276 & 0.06 & 276000 & 60000 & 2.05 & 4.4 \\
\hline 8 & 500 & 185 & 74 & 0.37 & 0.262 & 370000 & 262000 & 1.85 & 3.8 \\
\hline mean & 375 & 154.8 & 59.5 & 0.3965 & 0.235 & 396500 & 235000 & 17.625 & 3.725 \\
\hline
\end{tabular}

c.The results of Author's research

Table 3:- Standart Cast Brass Production Process.

\section{Expectations final sigma value after repair}

From the result of the expected improvement to changes sixma better than ever. This means that an increase in the value of sixma according to the desired expectations. After a four-month experiment in no change in the value of sigma.

Comparison of the sigma value of the production process before and after improvement as shown in Table 1 and 2 diagram is shown by the reduction in the number of defects of cast brass handicraft products of the mean value of 154,8 was reduced to 59,5 .

While the results of the calculation of the value of sigma defects cast brass handicraft products from 1.7625 sigma level or set of conditions becomes 3.725 sigma level 2 or level 4 in a state with the possibility of damage by 235,000 to a million times the production process.

Comparison of sigma and the mean value in the form of a diagram is shown in Figure 4 Comparison Sigma And Mean Value [19],[20].

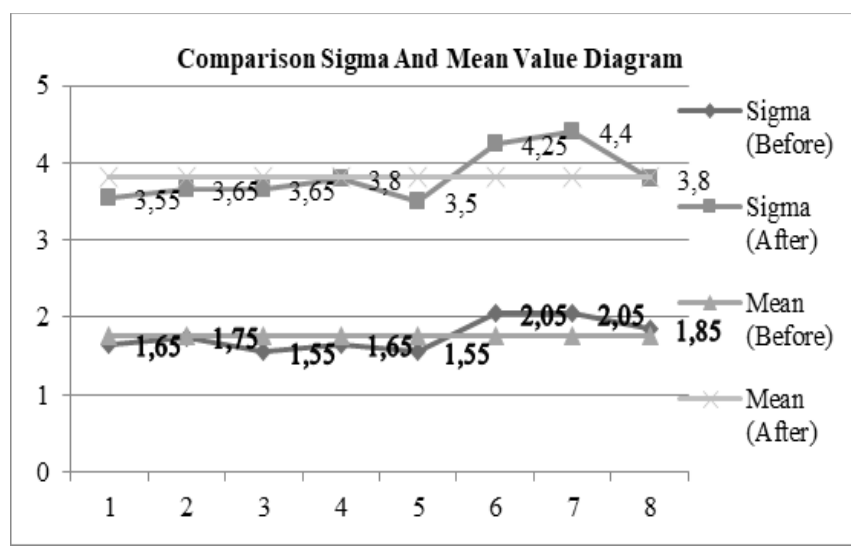

Fig 4:- Comparison Sigma And Mean

\section{CONCLUSION}

Application of a good standard production process based on standard SMEs cast brass crafts men. So as to reduce the number of defective products with calculation of the value of the rate sigma 1,7625 or are in levels 2 sigma before the repair, with possible damage to 396,500 to one million times the production process. Increased to levels sigma with the 3,725 level with possible damage to 235,500 to one million times the production process after repair. so the statisfaction of customers can be met with the assurance of product quality, and timeliness in accordance with the order.

\section{SUGGESTION}

Expansion of Majapahit's brass craft market segmentation through Ganesha cooperatives both locally and abroad using internet technology. The Ganesha Cooperative should actively participate in and conduct training or workshops in collaboration with government agencies (Disperindag) and competent private sector.

The Ganesha Cooperative should actively participate in exhibitions at home and abroad held by government or private agencies. Cooperative Ganesha to be active in marketing Majapahit cast brass handicraft products in collaboration with Artshop or star hotels

\section{REFERENCES}

[1]. B. Devipriyaand M. Nandhini,"AA Study on Consumer Attitude towards Eco-Friendly Products in Coimbatore City",International Journal of Management and Development Studies, vol. 5, pp. 15, https://www.ijmds.in/journalfile, 2016.

[2]. F. Handoko, E. Nursanti dan S. Sutriyono, "Aplikasi Pendekatan Perbaikan Terus Menerus guna Mencapai Green Industrial System yang Berkelanjutan", Prosiding SENATEK,1 (A), pp. 866-870, www. ejournal.itn.ac.id, 2015. [in bahasa] 
[3]. F. Handoko, E. Nursanti, G. Gatot, L. Mulyadi, J. Hutabarat dan Kustamar, "Green Industrial System in Indonesia", Journal of Telecomunication, Electronic and Computer Engineering, https://www.matecconferences.org/articles/matecconf, 2018.

[4]. L. Agnieszka, "Current Trends In The Consumer Behaviour Towards Eco-Friendly Products", Economic and Environmental Studies (E\&ES), vol.152,no.2,pp.115-

129,http://www.econstor.eu/handle/10419/178880, 2015.

[5]. D. Optimasi, H. Wahyono and F. Akurat, "Analysis Quality Control Of Batik Products", International Journal of Scientific \& Technology Research, vol. 7, no. 7, pp. 22-27,//www.ijstr.org, 2018.

[6]. A. Kholil and A. A. Jumhur.,"Waste Management Based on 3R in Mutiara Waste Banks Bekasi City Indonesia", International Journal of Scientific \& Technology Research, vol. 8, no. 3, pp. 7176,//www.ijstr.org, 2018.

[7]. Firmansyah"Meningkatkan Mutu Kain Tenun Ikat Tradisional Di Desa/Kelurahan Roworena Secara Berkesinambungan Di Kabupaten Ende Dengan Pendekatan TQM, "Institute of Technology National (ITN), Malang, vol. 3 issue 1, pp. 26-27, www. ejournal.itn.ac.id, 2017. [in bahasa]

[8]. E. Nursanti, R.I. ,Purnama dan I.B. Suardika, "Optimasi Kapasitas Produksi untuk Mendapatkan Keuntungan Maksimum dengan Linier Programin”, Performa : Media Ilmiah Teknik Idustri 14 (1), pp. 2223, www. ejournal.itn.ac.id, 2015. [in bahasa]

[9]. R.M.S. Avie dan E. Nursanti, "Aplikasi Continuos Improvement Terhadap Pemeliharaan Overhoul Pesawat Tempur Hawk Mk-209 TNI AU', Prosiding SENIATI, C. 108-C. 115, www. ejournal.itn.ac.id 2016. [in bahasa]

[10]. Mudit, Saxena, KVN. S. Rao "Quality Management, Total Quality Management And Six Sigma”, International Journal of Scientific \& Technology Research, vol. 8, issue 12, pp. 32-47,www.ijstr.org, 2019.

[11].S. Sahoo, and S. Yadav, "Effectiveness of Lean Manufacturing Technologies for Improving Business Performance: A studyof Indian Manufacturing Industries", World Academy of Science, Engineering and Technology : International Journal of Social, Behavioral, Educational, Economic, Business and Industrial Engineering, vol. 11, no.2, pp. 318325,https://publications.waset.org/10006349/effective ness-of-lean-manufacturing-technologies-onimproving-business-performance-a-study-of-indianmanufacturing-industries, 2017.

[12]. H. S. Al-Dhaafri, A. K. Al-Swidi, and R. Z. B. Yusoff, "The mediating role of total quality management between the entrepreneurial orientation and the organizational performance", The TQM Journal, vol. 28, no. 1, pp. 1754-2731, https://www.semanticscholar.org, 2016.
[13]. I. Mouludi, K. Rukun, N. Syah, S. Hafridana, M. I. Senjawati, B. H. Hayadi, "Expert System Design As A Quality Control Efforts In The Packaging Process Tea Rgb 220 Ml Package Bottle In Pt. Sinar Sosro Kpb Deli Serdang", International Journal of Scientific \& Technology Research, vol. 8, no. 6, pp. 8287,//www.ijstr.org, 2019.

[14].Z. Manalu, and Y. D. Lestari, "Project Effectiveness Improvement: A Case Study in PT.X," Journal of Bussiness and Management, vol. 4, pp. 587-593, https://journal.sbm.itb.ac.id, 2015.

[15]. Chockalingam, SN., and Isreal, DJ,.Redesigning, "The Marketing Mix For Eco-Friendly Product Consumption Among Non-Purchasers In India", Management \& Marketing: Challenges For The Knowledge Society, vol. 11, no. 1, pp. 355-370, https://doi.org/10.1515/mmcks, 2016.

[16]. B. Hermawan, S. Basalamah, A. Djamereng, A. Plyriadi, "Effect of Service Quality and Price Perception on Corporate Image, Customer Satisfaction and Customer Loyalty among Mobile Telecommunication Services Provider", IRAInternational Journal of Management \& Social Sciences, Vol.8, Issue 01 pp. 62-73, https://www.semanticscholar.org, 2017.

[17]. Makmur and Saprijal, "Strategi Pemasaran Dalam MeningkatkanVolume Penjualan (Studi Pada S-Mart Swalayan Pasir Pangairan)", Jurnal Ilmiah Cano Ekonomos, Vol.3, No.1, pp. 82-93, https://www.neliti.com/publications/58203/strategipemasaran-dalam-meningkatkan-volume-penjualanstudi-pada-s-mart-swalaya, 2015. [in bahasa]

[18]. S. Handayani, E. Nursanti dan F . Handoko, "Perencanaan Perbaikan Berkelanutan (CI-PDCA) Untuk Mewujudkan Efesiensi Energi Pada Sistem Perkantoran", Prosiding SENIATI, C. 139-C, https://www.semanticscholar.org, 2016. [in bahasa]

[19]. Brian, J. Galli, M. A. Kaviani,’The impacts of Risk on deploying and sustaining Lean Six sigma initiatives”, International Journal of Risk and Contingency Management, Volume 7, Issue 1, pp. 162-173, https://www.researchgate.net/publication/320740856 The_Impacts_of_Risk_on_Deploying_and_Sustaining Lean_Six_Sigma_Initiatives, 2018.

[20]. S. Elapanda, U.V.A. Rao, M. Manideep "Review On Effects Of Critical Social Factors In Application Of Lean Six Sigma For Manufacturing Industries", International Journal of Scientific \& Technology Research, ISSN 2277-8616,vol. 8, issue 11, pp. 72-83, //www.ijstr.org, 2019. 